\section{Revista de Literatura, História e Memória

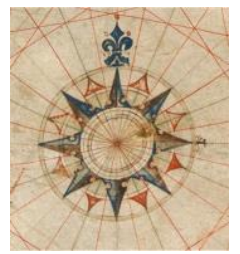 \\ Seção: Pesquisa em Letras no contexto Latino-americano e Literatura, Ensino e Cultura \\ ISSN 1983-1498 \\ VOL. 16 - No 28 - 2020 \\ U N I O E S T E / CA S C A V E L - p. 256-272}

\title{
MELANCOLIA COMO FORMA LITERÁRIA EM SÃO BERNARDO: UM VIÉS PSICANALÍTICO
}

\author{
Melancholy as a literary device on São Bernardo: a \\ psychoanalytical approach
}

José Roberto de Luna Filho ${ }^{1}$

RESUMO: O presente artigo propõe uma leitura do romance São Bernardo, de Graciliano Ramos, que considere a melancolia como um dispositivo formal essencial para a narrativa. Para tanto, utilizamo-nos as reflexões psicanalíticas sobre a condição melancólico e a partir dele consideramos os elementos da narrativa da obra que indiquem tal presença. Postulamos que Paulo Honório não possui uma personalidade monolítica, mas antes complexa e contraditória, e suas relações pessoais extrapolam a reificação e interesses econômicos: caso contrário, a morte de Madalena não lhe causaria o estado de letargia que o faz escrever o livro. Além disso, afirmamos que é a melancolia e seu desejo de autopunição que forçam o narrador-personagem a contar sua história.

PALAVRAS-CHAVE: São Bernardo; Graciliano Ramos; Literatura; Melancolia.

ABSTRACT: This works presents a different critical approach of São Bernardo, novel by Graciliano Ramos, which treats the melancoly as a literary device. For that, we based our analysis on a psychoanalytical view of that patology and searched for narrative clues that supports our hypothesis. We conclude that Paulo Honorio do not have a monolithic personality and his personal relationships are far from being based on a economic mentality: if that was not true, he never would become affected by a state of sorrow after the death of his wife, which leads him to write the book. Moreover we sustain that its the melancoly and a selfpunishment desire that forces the narrator to tell his life story.

KEYWORDS: São Bernardo; Graciliano Ramos; Literature; Melancoly.

\section{INTRODUÇÃO}

Graciliano Ramos é sem dúvida um dos autores mais importantes da literatura brasileira e talvez o mais importante romancista do século XX. Essa relevância fez com que os críticos das mais diversas orientações teóricas se ocupassem de sua obra. Seja pela forma de seus romances, aliando profundidade psicológica com o tratamento de problemas típicos da zona semiárida nordestina; seja pelo período literário conturbado em que escreve, o ficcionista alagoano sempre foi alvo de controvérsia, com muitos defendendo que ocupa um lugar à parte no movimento literário da década de $30 .^{2}$

\footnotetext{
1 Mestrando em Teoria da Literatura do Programa de Pós-graduação em Letras da Universidade Federal de Pernambuco (PPGL-UFPE)

${ }^{2}$ Cf. discussão realizada por Luís Bueno (2006).
} 
Focalizando uma das obras do autor, São Bernardo, objetivamos considerá-la sob um viés certamente minoritário ( $\mathrm{se}$ considerarmos os estudos clássicos sobre o escritor): o psicanalítico. Para sermos mais específicos, afirmaremos que a melancolia é um dispositivo formal fundamental, que atua em relação com a memória, para a interpretação dos eventos narrativos. Depois de analisar as evidências que sustentam nossa hipótese, discutiremos quais são as consequências de tal compreensão da obra.

O artigo está definido da seguinte forma: nas três primeiras seções, analisaremos a perspectiva crítica de três importantes estudos sobre a obra: os de Antonio Candido (2006), de Luis Carlos Lafetá (1994) e de Abel Barros Baptista, sendo este último o que propõe a leitura em que em parte nos basearemos para realizar esse estudo. Na quarta seção, discutiremos o sujeito Paulo Honório, isto é, quais suas características subjetivas que se revelam na narrativa; aqui discordaremos da posição de que se trata de um sujeito completamente orientado para a reificação das relações humanas. Na quinta, falaremos da memória como dispositivo literário da obra e de suas características modernas. Na sexta, trataremos da concepção de melancolia de acordo com os textos de Freud (2011) e Kristeva (1987). Na sétima, discutimos nossa proposta de leitura e por último fazemos as considerações finais do estudo.

\section{A POSIÇÃO DE ANTONIO CANDIDO (2006)}

Antonio Candido não coloca elementos sociológicos e contingenciais como se fossem centrais na obra de Graciliano Ramos; o crítico antes reconhece que a maior preocupação do escritor alagoano fora o homem. Tal afirmação sobre o conjunto da obra naturalmente se estende a São Bernardo. Para ele, este romance é uma análise psicológica da gênese do sentimento de propriedade numa personalidade incansável. Afirma, nas páginas iniciais de seu ensaio, que "[...] Paulo Honório [...] é modalidade duma força que o transcende e em função da qual vive: o sentimento de propriedade. (CANDIDO, 2006, p. 32). O crítico enfatiza as qualidades de selfmade man do personagem, saindo de uma condição paupérrima para a de um fazendeiro poderoso e temido. Além disso, é um homem de propriedade, “[...] gente para qual o mundo se divide em dois grupos: os eleitos, que têm e respeitam os bens materiais; os répobros, que não os têm ou não o respeitam" (CANDIDO, 2006, p. 33). A característica psicológica principal de Paulo Honório é, para Antonio Candido, portanto, o desejo de possuir, que se concretiza pelo emprego de métodos frios e precisos.

Esse crítico, porém, reconhece que o drama do livro gira em torno da negação desse 
sentimento de propriedade: Madalena, com quem se casa por amor, é a grande causadora do conflito. O amor é contraposição do sentimento de propriedade inerente a Paulo Honório, nega-o. Ainda segundo o que nos diz Candido (2006), é o desafio de Madalena às hierarquias da vida patriarcal da fazenda São Bernardo que ocasiona o ciúme e o medo do fazendeiro de perder o controle de suas posses. Esse ciúme, no entanto, é nada mais que a expansão do sentimento de posse que o personagem dirige a tudo o que o rodeia. Ou seja, os sentimentos de Paulo Honório por Madalena são, a um só tempo, genuínos e afetados pela sua lógica capitalista. $\mathrm{O}$ protagonista trava uma batalha contra tudo aquilo que foge ao exclusivo desejo de possuir.

É importante ainda ressaltar, para que não sejamos simplistas em relação à tese defendida por Antonio Candido, que para ele esse sentimento de propriedade não nasce de simples relações econômicas, mas antes de redes muito mais complexas:

Não se trata, evidentemente, do resultado mecânico de certas relações econômicas. Uma profissão, ou ocupação qualquer, é um todo complexo, integrado por certos impulsos e concepções que ultrapassam o objetivo econômico. E este todo complexo - como aprendemos nos romances de Balzac - vai tecendo em torno da pessoa um casulo de atitudes e convicções que se apresentam, finalmente, como a própria personalidade. (CANDIDO, 2006, p. 39).

E o autor conclui que a brecha para o lirismo, despertada por Madalena, desencadeia uma busca pelo controle, isto é, uma violência de Paulo Honório contra Paulo Honório, da qual nasce o livro São Bernardo, decorrente do desejo de confissão. ${ }^{3}$

\section{A POSIÇÃO DE JOÃO LUIZ LAFETÁ (1994)}

A análise empreendida por Lafetá (1994) difere da realizada por Candido, embora dela não discorde. Vejamos tais diferenças.

Em seu $O$ mundo à revelia, o autor posiciona como central à personalidade de Paulo Honório o sentimento de propriedade. Mas seu ensaio é mais longo que o pequeno trecho de Ficção e Confissão dedicado a São Bernardo, e se detém com maior profundidade na questão. O conceito-chave utilizado por Lafetá para entender a figura central do romance é o de reificação. Tal conceito nasce das relações econômicas, mas se espraia para toda a vida do sujeito, que passa a considerar o todo a sua volta com base em seu valor-de-troca:

\footnotetext{
${ }^{3}$ Antonio Candido trata novamente de São Bernardo em ensaio intitulado "Os bichos do subterrâneo", mas não identificamos qualquer mudança no tratamento dessa obra que seja digna de nota.
} 
A reificação é um fenômeno primeiramente econômico: os bens deixam de ser encarados como valores-de-uso e passam a ser vistos como valores-detroca e portanto como mercadoria. Mas sabemos que a consciência humana se forma no contato com a realidade, na atividade transformadora do mundo, que é produção de bens. Assim, as características do modo de produção infiltram-se na consciência que o homem tem do mundo, condicionando sem modo de ver e compondo-lhe, portanto, a personalidade. (LAFETÁ, 1994, p. 207).

A busca de Paulo Honório por São Bernardo é a mesma que a busca por Madalena: ambos os objetos do desejo são tratados como propriedades materiais a serem adquiridas. Para usar um possível sinônimo do termo que bem o traduz, pode-se dizer que Madalena é coisificada. Mas não apenas Madalena, pois, segundo Lafetá (1994), todas as relações estabelecidas por Paulo Honório se estabelecem a partir de critérios de valor-de-troca. E é isso que leva Madalena ao suicídio e Paulo Honório à frustração: a mulher se recusa a ser tomada como mero objeto; combate a tendência à reificação do marido em relação aos outros moradores da fazenda. Paulo Honório seria, enfim, um símbolo do capitalismo modernizante que chega ao nordeste entre as décadas de 20 e 30, bem como da burguesia, com sua personalidade objetiva, dinâmica, brutal e açambarcadora. E seu principal drama é não conseguir compreender a dimensão humana de sua esposa.

Há ainda outra diferença entre os ensaios de Candido e Lafetá a ser salientada: a questão da busca por controle. Como vimos acima, para Antonio Candido (2006) Madalena desperta em Paulo Honório lirismos que ele mesmo desconhecia e que busca conter. Para Lafetá (1994), no entanto, não há espaço para outro sentimento que não o da reificação, pois o que lhe arruína a vida não é a perda de controle de si mesmo, mas do mundo.

\section{A POSIÇÃO DE ABEL BARROS BAPTISTA (2005)}

O ensaio sobre Graciliano Ramos, presente n'O Livro Agreste (2005), de Abel Barros Baptista, contém questões que ultrapassam os limites deste trabalho. Por isso, restringiremos nosso comentário à parte de seu ensaio que trata de São Bernardo.

Realizando-se uma síntese acerca das posições anteriormente mencionadas sobre o romance, é possível dizer que, para Antonio Candido (2006), Paulo Honório é uma personalidade monolítica, cuja macicez apenas Madalena ameaça abalar; para Lafetá (1994), o fazendeiro é tão somente uma personalidade una. Abel Barros Baptista (2005), porém, põe em dúvida esse caráter da personalidade do personagem-narrador. Paulo Honório possui um fito na vida, delimita-o, calcula as ações e conta com uma ética pragmática, totalmente servil 
a seus interesses. Mas a narrativa demonstra, de modo sutil, que havia algo mais que o "fito" na vida do sertanejo: estamos em menos da metade do livro e seu objetivo já fora cumprido... que resta mais?

Um dia Paulo Honório acorda decidido a casar. Fantasia com uma mulher, mas casa com outra, o exato oposto. Quando comparece à casa do juiz, visando também a sua filha, encontra Madalena e o interesse é imediato; isto é, algo escapa ao projeto inicial: Paulo Honório sofre uma perda de domínio. E ele segue determinado ao casamento, que, ainda seguindo o raciocínio de Abel Barros Baptista, já se desvirtuara da vontade inicial de gerar um herdeiro: "a própria determinação mascara a ruptura e dá a Paulo Honório a ilusão de que faz o que quer, impedindo-o de se deter no fato de querer outra coisa e de ter com esse querer outra relação" (BAPTISTA, 2005, p. 109). O segundo ponto ressaltado pelo crítico português é o de que a ideia de se casar vai surgindo à mente de Paulo Honório ao mesmo tempo em que Madalena, pois antes de seu desejo repentino de gerar um herdeiro encontrara seus companheiros elogiando pernas e peitos de uma moça. O projeto se concretiza por acaso, de forma abrupta, quando encontra o objeto dos grosseiros elogios na casa do juiz.

Mais adiante, uma crucial distinção é feita pelo autor. Baseando-se em Aristóteles, Abel Barros Baptista (2005) diferencia cólera de ciúmes. Segundo ele, a cólera trata-se de um desejo de vigança por causa de qualquer dano que se tenha feito (ou pretendido fazer) ao colérico. $\mathrm{O}$ alvo não necesariamente é aquele que causou o desejo de vigança, podendo a raiva ser descarregada em outro. Para fixar um exemplo dado pelo próprio autor, vê-se a cólera em ação quando a raiva causada por Madalena em relação aos materiais escolares recai sobre Marciano. No romance, a cólera está sempre associada aos momentos em que o fazendeiro sente seu domínio sobre São Bernardo ameaçado; ou seja, a cólera decorre de seu sentimento de propriedade. Mas o ciúme é distinto. Quando Paulo Honório começa a exagerar os atributos físicos de outros homens e fantasiar o desejo de Madalena, nada ameaça sua propriedade. Ali ele está "destituído da condição de proprietário e reduzido à condição de homem" (BAPTISTA, 2005, p. 117). Quando tem ciúmes, a busca não é pela posse da terra, mas pelo domínio de si mesmo; o ciúme nasce do amor tão somente. E o crítico assim conclui a diferenciação proposta: "a cólera, reação violenta ao sentimento de propriedade molestado, é também um meio violento de defesa da posse e do domínio ameaçados; o ciúme domina e destrói, apenas" (BAPTISTA, 2005, 118).

Cabe, ainda, expor quais são as consequências da distinção entre o amor por Madalena e o sentimento de propriedade: se a cólera está relacionada ao sentimento de propriedade, ela eventualmente resultaria na consolidação da vingança, com a morte daquela que ameaça seu 
domínio: a esposa. Mas Paulo Honório não a mata, nem a ninguém: o que evita que isso aconteça é justamente o ciúme. Isso se deve ao fato de que o amor ultrapassa o sentimento de propriedade, Madalena está imune à reificação. Ao assim sucederem os acontecimentos, a narrativa recusa a tragicidade de um realismo.

\section{UMA PROPOSTA DE LEITURA DO SUJEITO PAULO HONÓRIO}

Os estudos críticos até aqui referenciados são de fundamental importância para uma compreensão mais ampla de um romance de tamanha complexidade literária como o é São Bernardo; mas, para a leitura que aqui proporemos, a que nos vai nortear é a de Abel Barros Baptista (2005). Como vimos acima, um dos argumentos centrais de sua perspectiva crítica é a de que Paulo Honório não se trata de uma criatura monolítica, ao contrário do que sugerem as leituras de inspiração teórica sociológica de Antonio Candido (2006) e Luiz Carlos Lafetá (1994). Ao concordar com tal posição, ressaltamos dois pontos, a serem ora desenvolvidos: Paulo Honório nem sempre tomou as decisões mais objetivas e precisas em sua história e a vida afetiva desse fazendeiro de São Bernardo não é determinada ou equivalente ao seu desejo capitalista de posse e de negócios.

Além dos sólidos argumentos levantados pelo crítico português em relação à personalidade supostamente objetiva de Paulo Honório, gostaríamos de adicionar mais alguns elementos da narrativa para, em seguida, defender uma posição mais radical. Logo no início da narrativa, precisamente no capítulo terceiro, o narrador-personagem, ainda cabra de eito, conta sobre sua relação amorosa com Germana, que termina em tragédia quando esta se “enxeriu” com João Fagundes, um ladrão de cavalos. Sabendo disso, Paulo Honório assassina seu rival e vai preso. Esse ato, logo no começo do romance, revela, antes de tudo, uma personalidade mais impulsiva, cruel e possessiva do que fria e calculista. Mas, em razão de ser antes de o protagonista empreender seus negócios pelo sertão e enricar, pode-se argumentar, corretamente, que até então ele era outro.

Na prisão, Paulo Honório aprende a ler e a fazer contas de aritmética, depois sai da cadeia e, como já dito, começa sua jornada em busca de capital. Quando dispõe de situação financeira favorável, o sertanejo volta a sua cidade natal e busca tomar posse das terras de São Bernardo. Mas é importante observar que não fica claro, na narrativa, o que surgiu primeiro: se a vontade de possuir São Bernardo ou a compreensão de que Luís Padilha, herdeiro, seria uma presa fácil. O fato é que Paulo Honório retorna ao seu município natal, lugar que, a princípio, não lhe ofereceria qualquer vantagem a mais que qualquer outra cidade, e ao chegar 
lá almeja justamente a fazenda onde, segundo ele, trabalhou no eito por 5 tostões. Vale lembrar que essa fazenda estava decadente, mal cuidada e sem qualquer tipo de produção; tanto que, posteriormente, dá muito trabalho para render alguma coisa. Não é negada pelo texto, portanto, a hipótese de que a escolha da fazenda São Bernardo como alvo de desejo de propriedade de Paulo Honório seja, mais uma vez, impulsiva, talvez influenciada por alguma relação que criou com a terra (amor ou ódio?) quando lá trabalhou.

Há ainda outros elementos da narrativa que demonstram que o caráter de Paulo Honório é bastante complexo. Lembremos, pois, de quando, no capítulo 7, Paulo Honório chama Seu Ribeiro para ser seu guarda-livros tão somente por ter com ele simpatizado. Ou de quando, de modo imprudente, ele vai atrás do jornalista Costa Brito apenas para lhe castigar e acaba tendo de se resolver com a polícia. Ou mesmo quando, após o assassínio de Mendonça, resolve proteger as suas filhas.

Se esses acontecimentos narrativos acima expostos têm certa debilidade em provar que a personalidade de Paulo Honório é bem menos maciça do que parece, a sua relação com Margarida efetivamente dá maior força ao argumento utilizado por Abel Barros Baptista (2005). Primeiro, Paulo Honório empreende uma busca por Margarida, a mulher que o criou quando criança. Não se trata de uma procura indiferente por alguém de seu passado, mas antes uma busca guiada pelos sentimentos de falta e nostalgia que lhe retiram lamentos: "Onde andaria a velha Margarida? Seria bom encontrar a velha Margarida e trazê-la para São Bernardo. Deve estar pegando um século, pobre negra" (RAMOS, 1994, p. 32). Paulo Honório aqui age de modo estranho a um sujeito de mentalidade puramente econômica, reificador das relações, pois empreende uma busca cara, baseado tão somente em gratidão ${ }^{4} \mathrm{e}$ saudade. Quando ele sabe que finalmente encontraram Margarida, demonstra profunda exaltação, o que definitivamente não é indício de indiferença em relação ao caso: "Durante o jantar, Azevedo Gondim referiu o motivo de sua visita: tinha-se descoberto o paradeiro da velha Margarida. - Que está dizendo! E você calado, Gondim!”.5 E mais adiante:

Ó Gondim, já que tomou a empreitada, peça ao vigário que escreva ao padre Soares sobre a remessa da negra. Acho que acompanho vocês, vou falar a padre Silvestre. É conveniente que a mulher seja remetida com cuidado, para não se estragar na viagem. E quando ela chegar, pode encomendar as miçangas, Gondim. Como se chamam? (RAMOS, 1994, p. 48).

\footnotetext{
${ }^{4}$ Sobre o sentimento de gratidão pela doceira, lembremos o que Paulo Honório diz no capítulo 3: "[a] velha Margarida mora aqui em S. Bernardo, numa casinha limpa, e ninguém a incomoda. Custa-me 10 mil-réis por semana, quantia suficiente para compensar o bocado que me deu" (ibidem., p. 11).

${ }^{5}$ Ibidem., p. 47.
} 
É importante observar que a linguagem utilizada por Paulo Honório não se pode confundir com seus sentimentos efetivos. É bem verdade que o narrador utiliza, na passagem acima mencionada, de termos que normalmente se utilizariam com mercadorias; mas a empolgação e o cuidado parecem, antes, revelar mais uma peculiaridade expressiva que propriamente um sentimento de posse.

A passagem talvez mais memorável na relação entre Paulo Honório e Margarida ocorre no capítulo 10, após a velha haver chegado à fazenda e já estar alojada. O fazendeiro envia uma carta de agradecimento ao vigário e logo após encontra a ex-doceira sentada numa esteira. Em seguida, inicia uma conversa cheia de respeito, a fim de saber como se ela se encontra, e Margarida responde que está gemendo e chorando com seus pecados, revelando seu rosto e corpo fatigados pela idade. É de notável o pesar que acomete o narrador neste momento:

Pecados! Antigamente era uma santa. E agora, miudinha, encolhidinha, com pouco movimento e pouco pensamento, que pecados poderia ter? Como estava com a vista curta, falou sem levantar a cabeça, repetindo os conselhos que me dava quando eu era menino. Uma fraqueza apertou-me o coração, aproximei-me, sentei na esteira, junto dela. (RAMOS, 1994, p. 56).

Na sequência, a figura agora frágil de Margarida continua a causar forte impressão ao narrador após ele afirmar estar disposto para dar o que seja necessário para a velha, que nega a necessidade de qualquer luxo. Nesse momento, aliás, Margarida revela uma desconfiança em relação à bondade do próprio Paulo Honório, pois diz que "quem dá o que tem a pedir vem". Mas a preocupação de Paulo Honório é sincera e ele sabe que nada tem a ganhar com a nada disso. E a maior prova é o sentimento de empatia e pena que transborda no trecho que encerra o capítulo, quando ela pede um tacho:

Lembrei-me do tacho velho, que era o centro da pequenina casa onde vivíamos. Mexi-me em redor dele vários anos, lavei-o, tirei-lhe com areia e cinza as manchas de azinhavre - e dele recebi sustento. Margarida utilizou-o durante quase toda a vida. Ou foi ele que a utilizou. Agora, decrépita, não podia ser doceira, e aquele traste se tornava inteiramente desnecessário. está bem, mãe Margarida, terá um tacho igual ao outro. (RAMOS, 1994, p. 57, grifo nosso).

Em suma, o que estamos propondo Paulo Honório intercala ao longo da narrativa ações vantajosas e calculadas com ações desvantajosas e impulsivas. Em vez de dizermos que o narrador-personagem de São Bernardo não é um sujeito mesquinho e de mentalidade cruel e capitalista, estamos dizendo que ele não é apenas isso. Essa concepção sobre ele é premissa 
fundamental para analisar a presença da melancolia na escrita do romance de São Bernardo, que começará agora desenvolvida.

\section{O PROBLEMA DA MEMÓRIA}

Afirmar que Paulo Honório é um sujeito complexo e contraditório evidentemente tem consequências para a compreensão da narrativa. Essa afirmativa, aliás, contraria o próprio narrador, que frequentemente assume um tom de tragicidade em relação à própria vida: para ele, sua vida agreste moldou seu caráter e determinou suas ações. Paulo Honório, em suma, concordaria com as teses de Antonio Candido e Lafetá sobre sua personalidade. Mas, se levamos em conta o que até aqui foi exposto sobre a personalidade do narrador, é possível afirmar que encontramos certo autodesconhecimento por parte do personagem, e mesmo certa incoerência psicológica, como a que Guido Mazzoni afirma ter-se iniciado nos romances de Dostoiévski: "Mantendo escondida ou inconsciente uma parte de si, os personagens de Dostoiévski possuem um direito à incoerência que os heróis do romance europeu nunca tiveram (MAZZONI, 2011, p. 330. Tradução nossa). Como já o reconheceu Antonio Candido (2006) em seu ensaio "Os bichos do subterrâneo", a prosa de Graciliano Ramos possui um caráter intimista (ainda que não perca seus elementos de crítica social) inegável, o que o aproxima do escritor russo. ${ }^{6} \mathrm{O}$ olhar profundo para o subsolo da alma humana faz emergir tanto na obra de Graciliano Ramos como na de Dostoiévski o autodesconhecimento e desarmonia em relação ao próprio self das personagens.

Resultado desse autodesconhecimento e incoerência psicológica é tanto a conclusão a que chega o "autobiógrafo" sobre si mesmo como o tom frequentemente exato, do ponto de vista temporal, que adota. Essa obsessão pela precisão numérica em relação a datas e valores, no entanto, é contraditória ao conteúdo do próprio livro, frequentemente impreciso. Embora a crítica quase sempre ressalte essa exatidão da escrita do romance, se ignoramos as aparências, percebemos que, na verdade, muito pouco fica claro, sobretudo de sua infância e mesmo de seu casamento, do qual sabemos apenas dos dissabores. É bem conhecido, por exemplo, o trecho em que o narrador afirma que se preocupa apenas em extrair o mais importante do evento, e o resto é bagaço. Mas isso ocorre um pouco depois de ele afirmar a imprecisão de sua memória. Imprecisão, aliás, que não é apenas nessa passagem que é questionada, pois no

\footnotetext{
${ }^{6}$ Embora isso não deva ser utilizado em absoluto como parâmetro, Graciliano Ramos efetivamente lia e apreciava Dostoiévski. Cf. as biografias de Dênis de Moraes (2012) e Ricardo Ramos (2011) sobre o escritor alagoano.
} 
capítulo 6 ele usa exatamente estas palavras: "Creio que foi mais ou menos o que aconteceu. Não me lembro com precisão" (RAMOS, 1994, p. 30). Mas esses elementos, embora não anulem em definitivo os muitos traços de precisão da narrativa (como as já mencionadas marcações temporais), servem antes para pensar a relação que o romance permite pensar entre a narrativa, o sujeito e a memória. Isso porque, em sendo uma narrativa contada em retrospectiva (isto é, sem a utilização de estilo indireto livre numa ação em que o personagem principal reflete enquanto os eventos estão ocorrendo), numa obra moderna, necessariamente a memória deixará marcas na montagem do ato de narrar. Entre o sujeito e a realidade existe um abismo intransponível: as palavras não possuem transparência. São Bernardo, como literatura moderna, traz implícita essa fratura do sujeito. É o que se convencionou chamar Crise do romance/narrador moderno (cf. ADORNO, 2003; BENJAMIN, 1987; ROSENFELD, 1973). Na escrita de São Bernardo, é a presença da melancolia do narrador que a um só tempo evidencia tais elementos da narrativa.

\section{UM INSTANTE COM FREUD E KRISTEVA}

Para dar prosseguimento à discussão acima iniciada, convém que sejam expostas as teses de Freud (2011), em seu Luto e Melancolia (Trauer und Melancholie), e de Julia Kristeva (1987), em seu Soleil Noir: Dépression et mélancolie. Aquele é um estudo inda hoje clássico sobre o tema pela perspectiva psicanalítica, de forma a ser impossível tratarmos do tema sem dele partir; este é um desenvolvimento feito com (e não a partir de) o estudo freudiano já citado sobre as veredas do simbólico e da escrita; além disso, a tese fundamental do livro, como se verá, justifica por si mesma a sua escolha como embasamento teórico. Comecemos pelo texto de Freud.

Atualmente possuímos um sem-número de terminologias para as doenças psicológicas, mas nem sempre foi assim. Quando em 1915 Freud empreende um esforço de compreensão acerca da melancolia, ele está ciente de que uma das dificuldades é a pluralidade de sintomas que caracterizam essa condição. O esforço do psicanalista é encontrar, dentre os muitos casos que a sua prática clínica conheceu, mas também em seu processo de autoanálise, aquilo que é constante e permite unificar as distintas experiências melancólicas.

Freud inicia seu texto comparando as causas e efeitos do sentimento de luto e da condição melancólica. O luto é decorrente da perda de alguém que se estima ou de alguma abstração (pátria, nobreza, respeito etc.) que seja relacionada a ela. Algumas das pessoas que sofrem essas perdas, porém, desenvolvem um estado considerado patológico, enquanto que 
nunca nos ocorre considerar o luto dessa forma, ainda que ele cause perturbações na vida cotidiana, sobretudo porque em certo momento esse estado cessará. O psicanalista observa que os sintomas do luto e da melancolia são similares (tristeza, desânimo, desinteresse pelo mundo, por exemplo), à exceção do rebaixamento de autoestima de que padece o melancólico.

Explica-nos, ainda, a causa do sentimento de tristeza que dá início ao trabalho de luto: a realidade da perda impõe a retirada da libido desse objeto, mas a resistência do homem em desistir de seus investimentos libidinais ocasiona a dor ${ }^{7}$, que só cessa aos poucos, conforme o princípio de realidade vai vencendo. O que diferencia esse processo de luto da melancolia é que a perda melancólica é ideal, isto é, não necessariamente causada pela morte (como o término de uma relação ou a perda de muito dinheiro). Quando ocasionada pela morte, Freud afirma que o doente sabe o que perdeu, mas não o que se foi junto com essa perda. Enquanto a perda do luto é concreta e consciente, a perda do melancólico permanece enclausurada no inconsciente.

Em passagem célebre sobre a melancolia, Freud descreve seu funcionamento, em passagem bastante esclarecedora:

Portanto, não há dificuldade alguma em reconstruir esse processo. Houve
uma escolha de objeto, uma ligação da libido a uma pessoa determinada:
graças à influência de uma ofensa real ou decepção por parte da pessoa
amada, essa relação de objeto ficou abalada. O resultado não foi o normal,
uma retirada da libido desse objeto e o seu deslocamento para um novo, mas
foi outro, que parece requerer várias condições para sua consecução. O
investimento de objeto provou ser pouco resistente, foi suspenso, mas a
libido livre não se deslocou para um outro objeto, e sim se retirou para o ego.
Lá, contudo, ela não encontrou um uso qualquer, mas serviu para produzir
uma identificação do ego com o objeto abandonado. Desse modo, a sombra
do objeto caiu sobre o ego, que pôde ser julgado por uma determinada
instância como um objeto, como o objeto abandonado. Assim, a perda do
objeto se transformou em perda do ego e o conflito entre o ego e a pessoa
amada em uma bipartição entre a crítica do ego e o ego modificado pela
identificação (FREUD, 2011, p. 61).

Ou seja, trata-se de um reinvestimento libidinal de inspiração narcísica, e a identificação produzida entre o Eu e o objeto perdido garante a manutenção da relação anterior à perda. Daí decorreriam as queixas dirigidas a si mesmo, que na verdade seriam direcionadas ao objeto perdido.

Apesar de este clássico trabalho de Freud ser fundamental para a compreensão do

${ }^{7}$ Freud (2011) nos diz, porém, que a caracterização desse sentimento do ponto de vista econômico não é simples de se entender. 
fenômeno melancólico, falta-lhe o exame de algo frequentemente associado aos que padecem dessa condição patológica: a sua sublimação por via do simbólico. É precisamente sobre essa reflexão que nos é cara a reflexão sobre a melancolia realizada por Julia Kristeva (1987). Em razão de sua ligação com a teoria dialógica de Bakhtin, a autora necessariamente não adora posturas teóricas dogmáticas; por isso, sua teorização se relaciona livremente com a de Freud, o que permite certas divergências de conteúdo e objetivo. Sua teoria sobre a melancolia não é inconciliável com a de Freud ou mesmo incompatível com a teoria psicanalítica, mas é distinta.

Esse livro questiona a relação entre os símbolos e os seres humanos. A necessidade de símbolos que permeiam nossa existência decorre de uma carência fundamental: a perda da mãe. ${ }^{8} \mathrm{O}$ simbólico é o meio por excelência de realizar o como se, a possibilidade encontrar um substituto às coisas que não mais possuímos. Para mantermo-nos em metáforas edipianas, um bom exemplo dessa relação entre símbolo-perda é o dedo e a chupeta que substituem o seio materno. Mas há ainda outro caminho para aqueles que sofreram uma perda: a retração do desejo. E é o que Kristeva afirma ser um traço central da melancolia. Isso se relaciona com a explicação freudiana de retração da libido para o ego, mas ilustra uma característica muito importante do melancólico: a dificuldade em fugir à sombra da patologia, verter em palavras os sentimentos e traumas; isso aliado à já mencionada falta de interesse pelo mundo. $\mathrm{O}$ melancólico se expressa, mas encontra sentido em se expressar apenas quando trata de sua própria melancolia. Ele mata seu desejo para se proteger (ou se punir?) da dor causada pela perda. E é precisamente essa inibição em relação aos símbolos e seu valor compensador que retiram a possibilidade de atribuir sentido à vida mesma: "Para o sujeito falante, a vida é uma vida que tem sentido: ela constitui mesmo o apogeu dos sentidos. Se esse sentido se perde, perde-se a vida mesma facilmente: sentido perdido, vida em perigo". (KRISTEVA, 1987, p. 16. Tradução nossa). O melancólico, em razão da perda de sentido, não consegue vislumbrar o futuro, e preso no passado se entrega à visão trágica da vida.

A melancolia, por isso, está associada a um doloroso processo de autoquestionamento e autorreflexividade: se o sujeito não é confortado pelos símbolos, desnaturaliza-os. É isso que deixa a vida em perigo. Para Kristeva, é nesse ponto em que a psicanálise pode ser um agente antidepressivo: o paciente deve ser capaz de conseguir religar sua vida às fontes de sentido, ser capaz de poder ressignificar a vida, através da análise. O que nos importa aqui é a

${ }^{8} \mathrm{O}$ que não deve ser entendido em seu sentido literal, pois é possível padecer da perda da mãe como objeto de desejo, mesmo possuindo uma. Trata-se de um processo simbólico presente na gênese dos seres humanos, envolvendo, naturalmente, o complexo de Édipo. 
necessidade que possui o melancólico de sublimar sua condição e tentar se religar ao sentido da vida. Nesse sentido, a escrita, seja ela memorialista ou filosófica, funciona como um importante meio de fazê-lo, tendo em vista a capacidade intrínseca desses gêneros para o questionamento dos signos da realidade ( $\mathrm{e}$, com frequência, capacidade de oferecer alternativas). Como demonstra Luis Costa Lima em seu Melancolia e Literatura (2017), a melancolia deixa entrever a criatura carente que há no homem, criatura essa que é igualmente revelada na literatura. Assim, embora a literatura não seja uma arte apenas para melancólicos, suscita no sujeito que escreve essa mesma carência essencial.

\section{ENFIM, A LEITURA MELANCÓLICA}

Para entender a relevância da análise da melancolia presente na obra de São Bernardo, é importante retrocedermos para pensar em sua escrita. Se existem coisas que não ficam claras no romance, a principal delas é o que leva Paulo Honório, sujeito avesso a literaturas, escrever um livro sobre sua vida. São já conhecidos os dois capítulos iniciais, que de certa formam justificam o acidente que foi o início da escrita. Mas é importante lembrar de duas coisas: 1- o que o faz efetivamente iniciar a escrita é o assombro causado pelo pio da coruja; 2- ao que tudo indica, esses dois capítulos foram os últimos a serem escritos por Paulo Honório (cf. o artigo de Abel Barros Baptista (2005) sobre os dois primeiros capítulos). Cabe perguntar, então: por que ele escreve? A resposta, cremos, é fundamental para a compreensão do romance, pois a narrativa dos fatos ficcionais do romance está subordinada a tal motivação, o que difere de um romance narrado em terceira pessoa por um narrador onisciente.

Paulo Honório, agora fazendeiro falido, passa os dias em letargia, até que um dia um pio de coruja o leva a escrever. Continua escrevendo e só toca novamente no assunto ao capítulo XIX, quando diz: "E, falando assim, compreendo que perco tempo. Com efeito, se me escapa o retrato moral de minha mulher, para que serve esta narrativa? Para nada, mas sou forçado a escrever" (RAMOS, 1994, p. 100). É notável que nessa passagem, escrita quando o narrador se encontra atormentado pelas lembranças do matrimônio, já mencione a esposa morta como relacionada à escrita de sua história, em contraposição ao "sei lá!" que dá como resposta à motivação do livro no capítulo II, que não deixa entrever qualquer motivo. Paulo Honório sente que precisa escrever e não pode parar de fazê-lo porque é afetado pelo sentimento de melancolia, um sentimento cuja motivação simplesmente lhe escapa: e fica assim, em eterno marasmo, dando voltas, mas sem entender com clareza sequer o que lhe acomete. Desse ponto de vista, é bastante agonizante pensar na sua situação: seu sofrimento é de tal forma 
enigmático que ele sequer sabe nomeá-lo.

Mas mesmo sem entender, e talvez sobretudo por não entender, Paulo Honório é acometido pela baixa autoestima característica do melancólico e de um desejo incontrolável de autopunição. É importante lembrar como seus atos mais vis são narrados sem qualquer inibição, sem que o narrador busque se defender de qualquer forma, ainda que tenha interesse de publicar o livro. Além disso, sente-se incapaz de escrever, sente seu relato fragmentado e dificultoso: não diz Kristeva (1987) que o melancólico sente dificuldade em se comunicar e que tudo o que diz é motivado pela própria melancolia? Paulo Honório não apenas sente dificuldade em elaborar suas dores, mas também culpa sua falta de instrução. Mas ele nunca foi ignorante: aprendeu a ler na cadeia e possuía tratados de agricultura. É de se questionar se sua dificuldade decorre tão só de inabilidade na escrita.

Supor que há uma melancolia na escrita de São Bernardo ${ }^{9}$ é pressupor uma causa e uma disposição. A disposição já tratamos mais acima, quando falamos sobre a complexidade de sua personalidade, mas agora daremos um tratamento mais completo à questão. Um Paulo Honório monolítico e dono de suas ações não poderia ser acometido por tal sentimento em razão da perda de sua esposa: bastaria arranjar outra, já que se trata de uma propriedade. Mas ele não o faz, e perde junto com a esposa a vontade de cuidar de sua fazenda. Isso porque Paulo Honório é um sujeito, como se demonstra desde o início, marcado por uma falta fundamental, que os símbolos da propriedade e do poder vêm apenas para sanar. Porém eles não são suficientes, e logo ele sente a necessidade de presenças afetivas: a mulher que lhe criou e uma esposa. Se existe algo em relação ao sentimento que Paulo Honório tem pela fazenda e por Madalena, é tão somente que ambos decorrem dessa carência fundamental, de quem nasceu e viveu na solidão arisca do sertão, sob eterna exploração dos mais fortes. Invertemos, portanto, a lógica da reificação: não é que Paulo Honório veja Madalena como sua posse, é que a mulher e a fazenda, ainda que de modos diferentes, a uma ordem que vai além da puramente econômica. Tanto que o amor por Madalena ultrapassa o amor pelas suas posses, tendo em vista que quando ela morre, o sertanejo perde qualquer interesse pela fazenda, assume sua invalidez.

Mas Madalena é ponto fulcral da narrativa porque revela em definitivo essa fratura exposta da personalidade de Paulo Honório. Ele sente necessidade de casar por impulso, e por acaso encontra sua futura esposa, quando outra tinha em mente. É acometido por um desejo

\footnotetext{
${ }^{9}$ Observe-se que evitamos ao máximo fazer diagnósticos clínicos de seres ficcionais, embora isso não seja exatamente equivocado. Antes preferimos falar que existe um sentimento melancólico que envolve a escrita de Paulo Honório.
} 
irrefreável, tanto que nada o para: nem as evidentes desvantagens de casar com essa moça. É preciso ter em conta que se trata de uma professora sertaneja, que não trará qualquer vantagem financeira ou política para seu marido. Tanto que ela já passava dos 25 anos sem ter sequer pretendentes. Ele se casa por amor, por isso que as vantagens da ordem econômica são sumariamente ignoradas. E mesmo as de gênio: já se sabe a aversão de Paulo Honório por quem trabalha com as letras.

O acontecimento decisivo na mudança da vida de Paulo Honório é quando seus ciúmes levam sua mulher a cometer suicídio, após discussão na igreja. E eis que é o canto da coruja, as que existiam aos montes na igreja da fazenda (será a rasga-mortalha, também conhecida como coruja de igreja, que remeteria duplamente a sua ex-mulher?) sente um estremecimento que o força a escrever. É precisamente esse evento que o leva a repensar toda a trajetória de sua vida (tanto que, finda essa parte, também nada mais há a contar), a fim de elaborar seu sofrimento e pôr em prática um como que desejo sádico de autopunição. E, motivado pela melancolia, conclui que nada poderia ser diferente de sua vida: sua vida agreste é a principal responsável, nada poderia ter sido diferente.

Como já dito acima, é um dos sintomas característicos da melancolia a estagnação no tempo e visão trágica da vida. Na pintura Saturno devora a un hijo, de Francisco de Goya (1746-1828), onde o titã Saturno, símbolo mitológico da bílis negra, desesperado devora a mais um de seus filhos, lutando desesperado contra o próprio trágico destino. Em Melencolia I, Albrecht Dürer (1471-1528) retrata um quadrado com diversos números, cuja soma é sempre 34. Pode-se pensar em duas possibilidades de interpretação. Que será essa inevitablidade do mesmo resultado senão o sentimento trágico ligado à melancolia? Enquanto um herói da tragédia clássica diria que os números são escolhidos em razão do mesmo resultado, inevitável, a fórmula de Paulo Honório é de que não poderia haver outro resultado, independentemente de quais números se escolha. É evidente que a vida de Paulo Honório poderia ser outra, mas muito da força de São Bernardo como obra ficcional decorre justamente da sua capacidade de captar a inexorabilidade da melancolia.

\section{CONSIDERAÇÕES FINAIS}

Os sentimentos oriundos da condição melancólica estão presentes na escrita da vida de Paulo Honório, como acreditamos ter conseguido demonstrar. Mas mais importante que isso é constatar suas consequências para a consideração crítica da obra. Os eventos narrados pelo narrador-personagem, bem como suas avaliações de si mesmo, não podem ser avaliados senão 
através de um filtro, devem ser considerados oriundos primeiramente da letargia que afeta o autobiógrafo ficcional. Isso, aliado a outras evidências presentes na obra, permite que reavaliemos tanto sua personalidade, como sua relação com os demais personagens, mormente Madalena. Além disso, permite que vejamos a melancolia como um dos elementos centrais, que funciona, junto à memória, como dispositivo formal. Podemos dizer que nessa obra a melancolia é ponto de partida e também de chegada.

O uso da memória e da melancolia como elementos estéticos permite, ainda, que consideremos a relação entre São Bernardo e o movimento regionalista de 30. Se é verdade que essa deve ser considerada obra regionalista, tampouco se lhe deve negar o caráter moderno (que é diferente de ser considerado uma obra modernista). Isso quer dizer que o livro não se confunde com uma tradição neoclássica, mas antes está alinhado com o que se fez na literatura moderna ocidental, a exemplo dos livros de Marcel Proust, Virginia Woolf e, sobretudo, William Faulkner. Esse debate, porém, exige um tratamento à parte, então deixemo-lo para discussões futuras.

\section{REFERÊNCIAS BIBLIOGRÁFICAS}

ADORNO, T. Posição do narrador no romance contemporâneo. In: Adorno, T. W. Notas de literatura I. Tradução de Jorge M. B. de Almeida. São Paulo: Duas cidades; Editora 34, 2003.

BATISTA, A. B. O livro agreste: Ensaio de curso de literatura brasileira. Campinas: Editora da UNICAMP, 2005.

BENJAMIN, W. O narrador: considerações sobre Nikolai Leskov. In: Benjamin, W. Magia, técnica, arte e política: ensaios sobre literatura e história da cultura. Tradução de Sérgio Paulo Rouanet. 7. ed. São Paulo: Brasiliense, 1987.

BUENO, L. Uma história do romance de 30. São Paulo: Edusp; Campinas: editora da UNICAMP, 2006.

CANDIDO, A. Ficção e confissão. In: Candido, A. Ficção e confissão: Ensaios sobre Graciliano Ramos. 3. ed. Rio de Janeiro: Ouro sobre azul, 2006.

CANDIDO, A. Os bichos do subterrâneo. In: Candido, A. Ficção e confissão: Ensaios sobre Graciliano Ramos. 3. ed. Rio de Janeiro: Ouro sobre azul, 2006.

COSTA LIMA, L. Melancolia e literatura. São Paulo: Editora UNESP, 2017.

FREUD, S. Luto e melancolia. Tradução de Marilene Carone. São Paulo: Cosac Naify, 2011. KRISTEVA, J. Soleil noir: Dépression et mélancolie. Paris: Gallimard, 1987. 
LAFETÁ, L. C. O mundo à revelia. In: Ramos, G. São Bernardo. 61. ed. Rio de Janeiro: Editora Record, 1994.

MAZZONI, G. Teoria del romanzo. Bologna: il Mulino, 2011.

MORAES, D. de. O Velho Graça: uma biografia de Graciliano Ramos. São Paulo: Boitempo, 2012.

RAMOS, G. São Bernardo. 61 ed. Rio de Janeiro: Editora Record, 1994.

RAMOS, R. Graciliano: Retrato Fragmentado. 2. ed. São Paulo: Globo, 2011.

ROSENFELD, A. Texto/Contexto: ensaios. 2. ed. São Paulo: Perspectiva, 1973. 